\title{
Yield and quality of maize following the foliar application of a fertilizer based on the byproduct "shale water"
}

\author{
Rafael da Silva Messias ${ }^{1,2^{\star}}$, Vanessa Galli ${ }^{1,3}$, Manoel Artigas Schirmer ${ }^{2}$, Clenio Nailto Pillon ${ }^{1}$, \\ Sérgio Delmar dos Anjos e Silva ${ }^{1}$, Carlos Augusto Posser Silveira ${ }^{1}$, Cesar Valmor Rombaldi ${ }^{2}$ \\ ${ }^{1}$ Embrapa Clima Temperado, Pelotas, Brazil; ${ }^{*}$ Corresponding Author: rafael.embrapa@yahoo.com.br \\ ${ }^{2}$ Faculdade de Agronomia Eliseu Maciel, Universidade Federal de Pelotas, Pelotas, Brazil \\ ${ }^{3}$ Centro de Biotecnologia, Universidade Federal do Rio Grande do Sul, Porto Alegre, Brazil
}

Received 24 September 2013; revised 2 November 2013; accepted 28 November 2013

Copyright (C) 2013 Rafael da Silva Messias et al. This is an open access article distributed under the Creative Commons Attribution License, which permits unrestricted use, distribution, and reproduction in any medium, provided the original work is properly cited.

\begin{abstract}
The water extracted from the shale rock (shale water) through the pyrolysis process to obtain fuel oil and other products shows a composition based on organic compounds and a wide range of minerals and trace elements with an important role in plant nutrition, suggesting its use as a fertilizer. Thus, the influence of foliar application of shale water (SW), with or without the micronutrients zinc ( $\mathrm{Zn})$, manganese $(\mathrm{Mn})$, copper $(\mathrm{Cu})$, boro (B) and molybdenum (Mo), was evaluated regarding yield and quality of maize grains. The yield, the total antioxidant activity, and the content of starch, phenolic compounds and carotenoids were improved in maize grains following the application of three doses of $7 \mathrm{~L} / \mathrm{ha}$ of SW, which indicates that SW may influence the primary and secondary metabolisms. The application of SW with micronutrients resulted in the increase of grain yield; however, did not result in the improvement of grain quality. The foliar fertilizer formulations also had an influence in the content of minerals and aminoacids of the grain. The results indicate that SW has potential to be used in agriculture to improve yield and quality of maize.
\end{abstract}

Keywords: Maize; Shale Water; Foliar Application; Grain Quality; Biofortification

\section{INTRODUCTION}

Nowadays, the search for food with nutritional and functional quality, free of toxic residues, as well as environmental friendly produced, is a worldwide tendency.
Major cereal crops are staple foods that have the role to provide great amount of dietary macronutrients such as carbohydrates, lipids and proteins, micronutrients such as minerals and vitamins, as well as functional compounds, which can improve human health [1,2]. In particular, maize is one of the major crops cultivated over the world, mainly in developing countries, with a varied range of consumed forms and utilizations. Because of this, the efforts for the biofortification of this crop are of interest $[3,4]$.

Maize grains are a considerable source of poliphenol antioxidants, especially phenolic acids such as ferulic, caffeic and $\rho$-cumaric acids [5]. This cereal also displays great natural variation for carotenoid composition, including the xanthophylls lutein and zeaxanthin and vitamin A precursor's $\alpha$-carotene, $\beta$-carotene, and $\beta$-cryptoxanthin $[2,6]$. Most of these compounds have an important role as antioxidants and regulators of the human immune system, resulting in the prevention of cardiovascular diseases, as well as several types of cancer and other age-related diseases [4,7]. Therefore, phenolic compounds and carotenoids are important targets for biofortification efforts, especially vitamin A precursors, because the dietary deficiency of vitamin A is related to eye diseases in many developing countries that have maize as their major dietary source [8].

The increase in agricultural production and the purity of industrial fertilizers have resulted in depletion of soil and reduction of micronutrients phytoavailability; therefore, the application of fertilizers have become an important biofortification approach to increase mineral content, especially in cereal grains, that are relatively poor sources of mineral nutrients [3]. However, studies about mineral fertilization have been focused in the improvement of carotenoids and phenolic compounds content are 
scarce in the literature. Moreover, one bottleneck of this agronomic intervention is the cost and environmental impact of solid fertilizers, since a great part of them is leached [9]. Thus, new investigations on alternative and natural sources of fertilizers and/or biostimulant products, able to deal with the gradual poorness of soil, and to maximize plant mineral uptake resulting in benefits in grain quality and yield, are of great interest.

Foliar fertilization with micronutrients has been intensively used in the late years because this practice allows the application of minerals at the appropriate time during plant development (according to plant needs), it allows uniformity in nutrient distribution and increase in the nutrient absorption, and consequently it avoids losses in the environment [10]. Nowadays, the use of bioactive substances, such as chitosan, benzothiadiazole, glyphosate, salicylic acid and some phytohormones, which can be applied concomitantly with the foliar fertilizer, have also shown promising results in influencing plant growth and development, playing a role on gene expression, plant defense metabolism, and in the mineral nutrients uptake [11].

The chemical composition of shale water (SW), the constituent water of shale pyrobituminous rock, which is extracted during the pyrolysis process to obtain, for instance, fuel oil, sulfur and gas (LPG), was recently described [12]. The composition of SW is based on several organic compounds, mainly phenols, as well as minerals and trace elements of interest for plant nutrition. The application of SW in lettuce [12] and pepper [13] plants resulted in the increase of yield and mineral content, suggesting its potential as a foliar fertilizer. Furthermore, a previous study was performed in order to evaluate the food safety of using SW in agriculture. To this purpose, SW was applied via foliar in the lettuce crop that was considered an excellent biological indicator of food quality, because it is usually eaten "fresh"; and environmental quality, because of its high susceptibility to contaminants. As a result, no harmful element or compound was detected in the lettuce leaves treated with SW, indicating that the use of SW as foliar spray in agriculture repre- sents an environmental friendly alternative for the disposal of this by-product [12]. Therefore, in the present study we evaluated the effect of foliar application of formulations based on SW, delivered with or without micronutrients enrichment, on vegetative growth, yield and quality of maize grains.

\section{MATERIAL AND METHODS}

\subsection{Experimental Design and Treatments}

The commercial maize hybrid 30F53 (Pioneer ${ }^{\mathrm{TM}}$ ) was grown on field in four rows per block, $10 \mathrm{~m}$ long, containing 20 plants per row. Plots were spaced $0.25 \mathrm{~m}$ apart within rows, with rows spaced $0.80 \mathrm{~m}$ apart. During sowing, $280 \mathrm{~kg} / \mathrm{ha}$ of the formula 10-20-10 (N-P-K) was applied, and 30 days after germination an application of urea $(90 \mathrm{~kg} / \mathrm{ha})$ was performed. The experimental block design was randomized, with five replications and five treatments, as follow: C, control (distilled water); DW-M, micronutrients diluted in distilled water; SW-M, micronutrients diluted in shale water; SW-1, 2.5 L/ha of shale water; and SW-2, 7 L/ha of shale water. The micronutrients used in the treatments DW-M and SW-M were: $8 \%$ zinc $(\mathrm{Zn})$ in the form of $\mathrm{ZnSO}_{4}, 1.5 \%$ manganese $(\mathrm{Mn})$ in the form of $\mathrm{MnSO}_{4}, 1.5 \%$ copper $(\mathrm{Cu})$ in the form of $\mathrm{CuSO}_{4}, 0.5 \%$ boro (B) in the form of $\mathrm{H} 3 \mathrm{BO} 3$ and $0.5 \%$ molybdenum (Mo) in the form of $\left(\mathrm{NH}_{4}\right) 6 \mathrm{Mo}_{7} \mathrm{O}_{24}$. All treatments were supplied with a surfactant plus mineral oil as adjuvant and adjusted to $\mathrm{pH} 5.5$ - 6.0 using chloridric acid (Vetec $\AA$, Rio de Janeiro, Brasil). The mineral and organic composition of the SW used in the experiment was previously describe [12] and is presented in Table 1. The applications of the formulations were performed with the use of a pressurised sprayer $\left(\mathrm{CO}_{2}\right)$ adjusted to an equivalent nozzle flow rate of $100 \mathrm{~L} / \mathrm{ha}$. Three applications of the treatments were performed: the first two applications occurred during the vegetative growth period (V6-V8 and V9-V10 stages, according to Hanway [14]), and the third application occurred during the reproductive phase (spraying flowering and pollination, stage R1, according to Hanway [14]). In these

Table 1. Chemical composition of the shale water used in the experiment.

\begin{tabular}{|c|c|c|c|c|c|c|c|c|c|c|}
\hline \multicolumn{11}{|c|}{ Mineral Composition } \\
\hline \multirow{2}{*}{$\mathrm{mg} / \mathrm{L}$} & $\mathrm{S}$ & $\mathrm{Na}$ & $\mathrm{Si}$ & $\mathrm{Cl}$ & As & $\mathrm{Se}$ & & & & \\
\hline & 595 & 2.74 & 1.22 & 0.3 & 1.19 & 0.98 & & & & \\
\hline \multirow{2}{*}{$\mu \mathrm{g} / \mathrm{L}$} & $\mathrm{Ca}$ & $\mathrm{K}$ & $\mathrm{Mg}$ & B & $\mathrm{Fe}$ & $\mathrm{Cu}$ & $\mathrm{Zn}$ & $\mathrm{Hg}$ & Mn & \\
\hline & 653 & 100 & 158 & 135 & 130 & 17.7 & 17.1 & 12 & 3.9 & \\
\hline \multicolumn{11}{|c|}{ Organic Composition } \\
\hline \multirow{2}{*}{$\mathrm{mg} / \mathrm{L}$} & Sulphate & Total Cresols & Cyanide & Toluene & Etilbenzene & m.p-Xilene & 4-Metilphenol & Phenol & 2-Metilphenol & 2.4-Dimetilphenol \\
\hline & 162 & 133 & 0.36 & 0.13 & 0.01 & 0.01 & 91.8 & 66.7 & 45.9 & 29.3 \\
\hline
\end{tabular}


stages the major nutritional demand of maize plants occurs [15].

\subsection{Yield of Maize Grains}

At physiological maturity (R6 stage, according to Hanway, 1966), the cobs from the useful area (two central rows) were harvested, dried at $65^{\circ} \mathrm{C}$ until approximately $13 \%$ moisture content, and weighed in order to evaluate yield of maize grains.

\subsection{Amino Acids Composition and Carbohydrate Content of Maize Grains}

The free amino acids were extracted from $50 \mathrm{mg}$ of lyophilized maize grains samples (at physiological maturity) with $25 \%$ acetonitrile in $0.1 \mathrm{~N}$ chloridric acid solution, using the Ez:faast kit from Phenomenex ${ }^{\circledR}$ (Torrance, $\mathrm{CA}$ ).

After centrifugation at $18.890 \mathrm{~g}$, the supernatant was filtered in a $0.45 \mu \mathrm{m}$ PTFE syringe and $2 \mu \mathrm{L}$ was injected in a gas chromatography (GC-FID, Shimadzu, Japan) with a capillary column ZB-AAA. The carrier gas used was $\mathrm{N}$, with the flow of the column adjusted to $2 \mathrm{~mL} / \mathrm{min}$ and pressure of $60 \mathrm{kPa}$. The flow rate valve was split 1:17 and the injection and detection temperature was 280 and $320^{\circ} \mathrm{C}$, respectively. The starch and the total soluble sugar (TSS) content of maize grains at physiological maturity were quantified by the method with anthrone [16]. All determinations were made in three analytical replicates and five field replicates.

\subsection{Mineral Composition of Maize Grains}

The mineral composition was determined in dried maize grains samples collected at physiological maturity. The nitrogen (N) and sulfur (S) content was carried out on CHN-S analyzer coupled (LECO ${ }^{2}$, St. Joseph, MI). The content of phosphorus $(\mathrm{P})$, potassium $(\mathrm{K})$, calcium $(\mathrm{Ca})$, magnesium $(\mathrm{Mg})$, copper $(\mathrm{Cu})$, iron $(\mathrm{Fe})$, manganese $(\mathrm{Mn})$ and zinc $(\mathrm{Zn})$ was quantified by atomic absorption spectrometry (AAS) (Varian ${ }^{\mathrm{TM}}$ AA240FS, Santa Clara, CA) from $250 \mathrm{mg}$ of sample digested with $1 \mathrm{~mL}$ of $\mathrm{H}_{2} \mathrm{O}_{2}$ and $5 \mathrm{~mL}$ of $\mathrm{HNO}_{3}$ in microwave, according to Da Silva [17]. Means value from three analytical and five field replicates were expressed as $\mathrm{g} / \mathrm{kg}$ DW for macronutrients and $\mathrm{mg} / \mathrm{kg}$ DW for micronutrients.

\subsection{Assessment of Secondary Metabolism}

\subsubsection{Antioxidant Activity, Phenolic Compounds and Carotenoid Content}

For the analyses of secondary metabolism, lyophilized grains collected at physiological maturity were crushed with mortar and pestle using liquid nitrogen. The antioxidant activity was determined according to Arnao et al.
[18]. The phenolic compounds were quantified by the method from Adom and Liu [19]. Total carotenoids content was quantified by the method from RodriguezAmaya and Kimura [20]. Data were calculated based on a $\beta$-carotene curve.

\subsubsection{Expression of Genes Involved in Carotenoid Biosynthesis}

To evaluate the expression of genes phytoene synthase (PSY1), carotenoid $\varepsilon$-hydroxylase (CYP97C) and $\beta$ carotene hydroxylase (HYD3), the entire maize grains collected at R4 stage [14], corresponding to the peak of expression of these genes [21], were crushed with mortar and pestle using liquid nitrogen. Three replicates of each sample were subjected to total RNA isolation using a CTAB modified protocol, previously adapted [22]. RNA quality was evaluated by electrophoresis on $1 \%$ agarose gel stained with ethidium bromide and by spectrometry, using A260/A280 and A260/A230 ratio and RNA concentration was measured in Qubit ${ }^{\circledR}$ fluorometer (InvitrogenTM, São Paulo, Brasil). One $\mu \mathrm{g}$ of total RNA was digested with $1 \mathrm{U}$ DNAse, and used for reverse transcription using M-MLV enzyme, according to manufacturer's instructions (Invitrogen ${ }^{\mathrm{TM}}$, São Paulo, Brasil). For RT-qPCR reactions, specific primers were designed on Vector NTI 11 Program (Invitrogen ${ }^{\mathrm{TM}}$, São Paulo, Brasil) for the amplification of CYP97C (F: 5'-GTTGACATTGGATGTGATTGG-3'， R: 5'-AACCAACCTTCCAGTATGGC-3'), PSY1 (F: 5'-GACAGATGAGCTTGTAGATGGGC-3', R: 5'-TCAGAGAGAGCGGCATCAAGCA-3'), HYD3 (F: 5'-GGGGATTACGCTGTTCGG-3', R: 5'-GTGGTGTATCTTGTGCGAGG-3'), ACT (F: 5'CATGGAG-AACTGGCATCACACCTT-3', R: 5'-CTGCGTCATTTTCTCTCTGTTGGC-3'), GAPDH (F: 5'ACTGTTCATGCCATCACTGC-3', 5'-GAGGACAGGAAGCACTTTGC-3') and UBI (F: 5'-GTTTAAGCTGCCGATGTGCCTG-3', R: 5'-GACACGACTCATGACACGAACAGC-3'). All amplicons were designed to be less than $150 \mathrm{bp}$. ACT and UBI were used as reference genes and $\mathrm{C}$ treatment as reference sample. The efficiency of these primers was previously verified in real time PCR, which was close to $100 \%$. The PCR conditions used were as follows: final volume of $20 \mu \mathrm{l}$ containing 150 ng of cDNA, 3 - 10 pmol of each primer, 3 $5 \mathrm{mM} \mathrm{MgCl}_{2}, 10 \mu \mathrm{L}$ Platinum Sybr UDP Mix (Invitrogen $^{\mathrm{TM}}$, São Paulo, Brasil). The amplification was standardized in 7500 Fast thermal cycler (Applied BiossystemsTM, Carlsbad, Califórnia) using the following conditions: $50^{\circ} \mathrm{C}$ for $20 \mathrm{~s}, 95^{\circ} \mathrm{C}$ for $10 \mathrm{~s}$, followed by $40 \mathrm{cy}-$ cles of $15 \mathrm{~s}$ at $95^{\circ} \mathrm{C}$ and $60 \mathrm{~s}$ at $60^{\circ} \mathrm{C}$. Melt curve conditions used was: $15 \mathrm{~s}$ at $95^{\circ} \mathrm{C}, 60 \mathrm{~s}$ at $60^{\circ} \mathrm{C}, 30 \mathrm{~s}$ at $95^{\circ} \mathrm{C}$ and $15 \mathrm{~s}$ at $60^{\circ} \mathrm{C}$. The PCR product was subjected to electrophoresis on $1 \%$ agarose gel for verification of unspecific bands. The housekeeping genes actin (ACT), 
ubiquitin (UBI) and glyceraldehyde 3-phosphate dehydrogenase (GAPDH) were used as reference genes. The $\mathrm{Cq}$ values obtained were analyzed according to $2^{-\Delta \Delta \mathrm{Ct}}$ method and presented as fold change [23].

\subsection{Statistical Analysis}

The results were subjected to analysis of variance between treatments with a confidence p-level of $1 \%$ or $5 \%$ by Tukey average test. Spearman's test was used to correlate treatments. All statistical analysis was conducted on Systems Analysis Software and graphs were prepared in GraphPad Prism 5.

\section{RESULTS}

\subsection{Evaluation of the Foliar Application of SW on Grain Yield}

The yield of maize following the application of three doses of $7 \mathrm{~L} /$ ha of SW (SW-2) was statistically higher than the control and similar to the yield of maize following the application of micronutrients (DW-M), suggesting that the SW may be used as an alternative. In contrast, the application of three doses of $2.5 \mathrm{~L} / \mathrm{ha}$ of SW (SW-1) did not increase the weight and yield values, indicating a dose dependent effect (Figure 1(a)). The enrichment of SW with micronutrients (SW-M) also resulted in yield improvement compared to control. This is in agreement with studies showing that micronutrients may play a role in the synthesis and translocation of photoassimilates $[3,24]$. The SW-M treatment showed similar yield as SW-2 treatment; therefore, the application of SW-M represents an alternative strategy instead of SW-2, if yield is the parameter of interest, because the treatment SW-M has a lower dose of SW than SW-2 treatment.

\subsection{Evaluation of the Foliar Application of SW on Starch and TSS Accumulation in Maize Grain}

The treatments with doses of SW (SW-1 and SW-2) showed statistically more starch accumulation than the others at physiological maturity (Figure 1(b)), which is in agreement with the results of yield for these treatments (Figure 1(a)). However, only SW-2 treatment showed high starch/TSS ratio, whereas SW-1 treatment showed great amounts of TSS, which could have a negative effect because grains with high TSS content are more susceptible to insect attacks during storage. Furthermore, the application of SW supplemented with micronutrients (SW-M) did not result in starch accumulation improvement, which suggests that SW contribution was higher than micronutrient supplementation regarding starch accumulation.

\subsection{Evaluation of the Foliar Application of SW on Free Amino Acids Content in Maize Grains}

The evaluation of free amino acids in maize grains at R4 stage showed that foliar application with the highest dose of SW (SW-2) resulted in the improvement of alanine, proline, valine and asparagines content, compared to control (Figure 2). However, the same result was not observed in the SW-1 treatment, which increased only tyrosine and valine content, indicating that the accumulation of some amino acids is dependent of the dose of SW applied. When SW was enriched with minerals (SW-M), the content of aspartic acid, treonine, alanine and glycine was improved, compared to DW-M treatment, showing the influence of the interaction between SW and minerals supplied.

\subsection{Evaluation of the Foliar Application of SW on Mineral Content in Maize Grains}

The foliar fertilization of maize with SW-2 resulted in increase in the accumulation of $\mathrm{K}, \mathrm{Cu}, \mathrm{Fe}, \mathrm{Mn}$ and $\mathrm{Zn}$ in grains, compared to the control (Table 2). No significant difference in mineral accumulation was observed between the two doses of SW applied (SW-1 and SW-2).

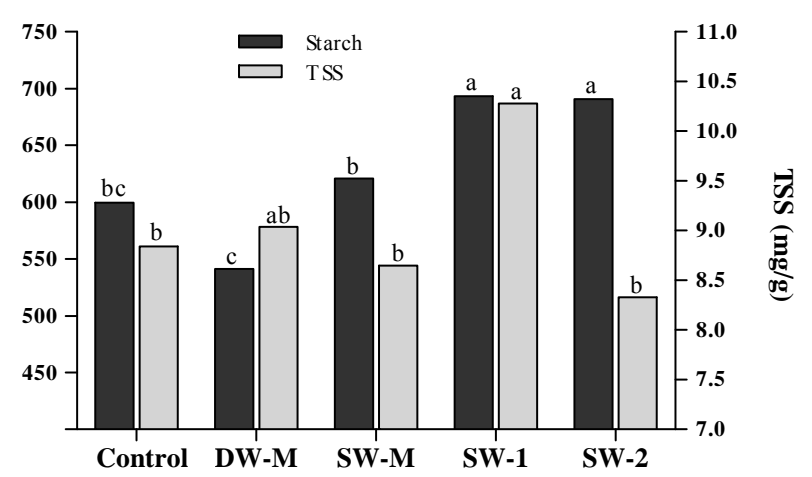

(b)

Figure 1. a) Yield of maize grains; b) Starch and total soluble sugars (TSS) content in maize grains at harvest. Different letters represent significant difference at $5 \%$ confidence level by Tukey test between treatments for the same dependent variable. 

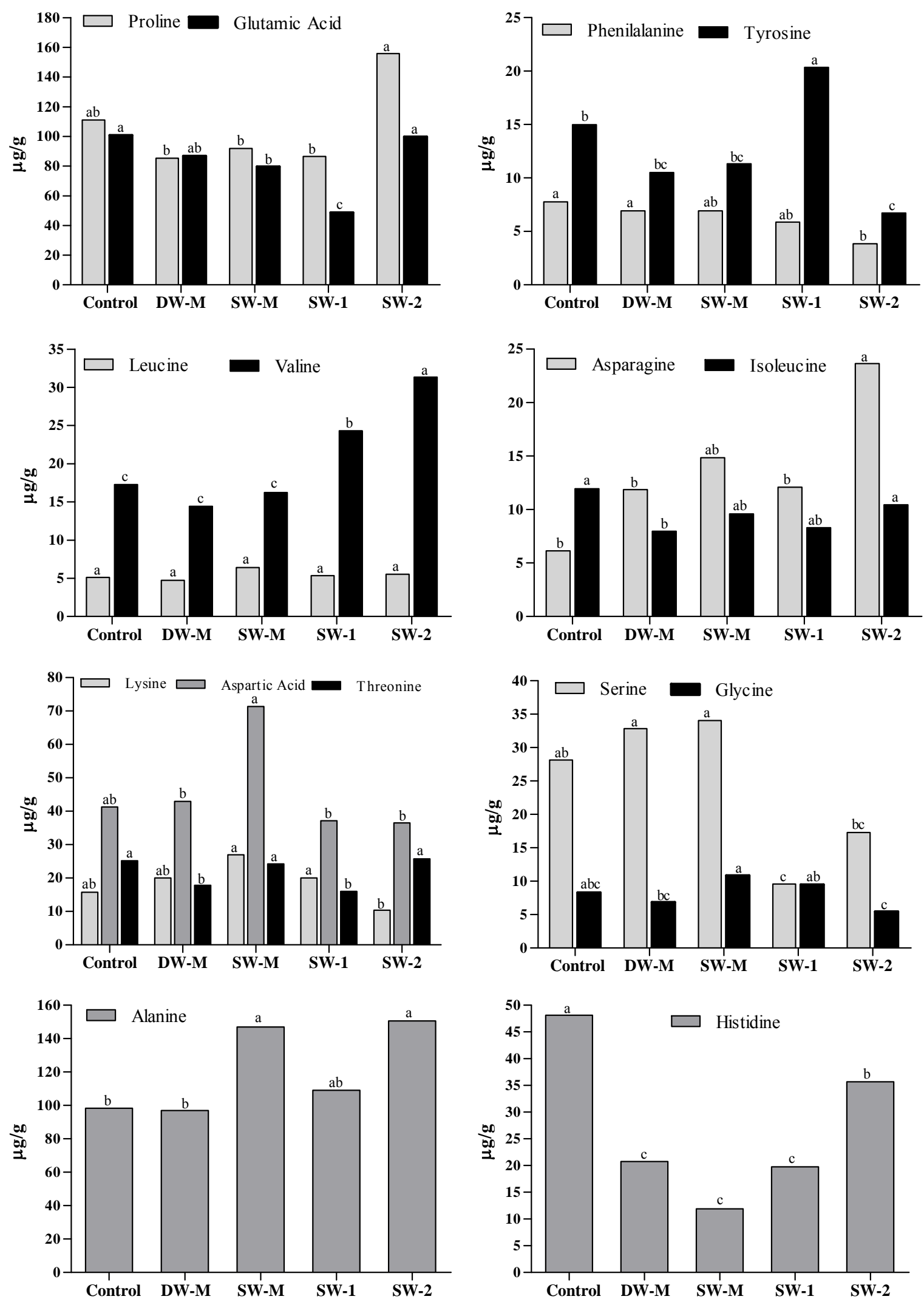

Figure 2. Free amino acids content in maize grains collected at R4 stage. Data shows means of three field and analytical replicates. Different letters represent significant difference at $5 \%$ confidence level by Tukey test for the same dependent variable. 
Table 2. Mineral composition of maize grains treated with foliar fertilizer formulations.

\begin{tabular}{|c|c|c|c|c|c|c|c|c|c|c|c|c|c|c|c|c|c|c|c|c|}
\hline \multirow{2}{*}{$\begin{array}{c}\text { Mineral } \\
\text { Treatment }^{1} \\
\end{array}$} & \multicolumn{2}{|c|}{$\mathbf{N}$} & \multicolumn{2}{|l|}{$\mathbf{P}$} & \multicolumn{2}{|c|}{$\mathbf{K}$} & \multicolumn{2}{|c|}{ Ca } & \multicolumn{2}{|c|}{ Mg } & \multicolumn{2}{|c|}{$S$} & \multicolumn{2}{|c|}{$\mathbf{C u}$} & \multicolumn{2}{|c|}{$\mathbf{F e}$} & \multicolumn{2}{|c|}{ Mn } & \multicolumn{2}{|l|}{ Zn } \\
\hline & & & & & & & kg & & & & & & & & & mg & kg & & & \\
\hline $\mathrm{REF}^{2}$ & - & & 2.100 & & 2.870 & & 0.070 & & 1.270 & & - & & 3.140 & & 27.000 & & 4.850 & & 22.100 & \\
\hline Control & 10.320 & $\mathrm{Cd}^{3}$ & 3.271 & A & 2.185 & B & 0.069 & A & 0.912 & A & 1.262 & A & 1.817 & $\mathrm{D}$ & 13.333 & $\mathrm{C}$ & 3.350 & $\mathrm{D}$ & 11.970 & $\mathrm{D}$ \\
\hline DW-M & 10.950 & $\mathrm{Bc}$ & 2.869 & A & 2.472 & $\mathrm{Ab}$ & 0.044 & $\mathrm{Bc}$ & 0.816 & A & 1.248 & A & 2.938 & $\mathrm{C}$ & 14.500 & $\mathrm{Bc}$ & 4.600 & $\mathrm{Bc}$ & 19.495 & $\mathrm{Bc}$ \\
\hline SW-M1 & 12.508 & A & 3.013 & A & 2.864 & A & 0.066 & A & 0.809 & A & 1.303 & A & 3.300 & $\mathrm{~B}$ & 16.650 & A & 5.230 & $\mathrm{Ab}$ & 21.462 & $\mathrm{Ab}$ \\
\hline SW-1 & 11.578 & $\mathrm{Ab}$ & 3.147 & A & 2.878 & A & 0.070 & A & 0.865 & A & 1.315 & A & 3.550 & $\mathrm{Ab}$ & 14.150 & $\mathrm{Bc}$ & 5.150 & $\mathrm{Ab}$ & 18.403 & $\mathrm{C}$ \\
\hline SW-2 & 11.240 & $\mathrm{Bc}$ & 3.352 & A & 2.934 & A & 0.055 & $\mathrm{Ab}$ & 0.848 & A & 1.304 & A & 3.780 & A & 15.730 & $\mathrm{Ab}$ & 5.710 & A & 18.972 & $\mathrm{C}$ \\
\hline
\end{tabular}

${ }^{1}$ Control - control without foliar spray; DW-M-formulation with micronutrients in distilled water $(2.5 \mathrm{~L} / \mathrm{ha})$; SW-M-formulation with the same micronutrients concentration of DW-M in shale water (SW) $(2.5 \mathrm{~L} / \mathrm{ha})$; SW-1 and SW-2 - shale water applied at rates equivalent to $2.5 \mathrm{~L} / \mathrm{ha}$ and $7 \mathrm{~L} /$ ha, respectively. ${ }^{2} \mathrm{All}$ values from USDA National Database for Standard Reference. Available in: www.ars.usda.gov/nutrientdata. ${ }^{3}$ Mean of five field and two analytical replicates and statistical significance at $5 \%$ level of confidence by Tukey test for the same dependent variable.

The enrichment of foliar treatments with the micronutrients $\mathrm{Zn}, \mathrm{Cu}, \mathrm{Mn}$, Mo and B (DW-M and SW-M) significantly increased the levels of $\mathrm{Zn}, \mathrm{Cu}$ and $\mathrm{Mn}$ on maize grains, compared to control, and the application of SW$\mathrm{M}$ treatment resulted in the accumulation of $\mathrm{Zn}$ in higher concentration than SW delivered alone (SW-1 and SW-2). SW-M treatment also increased N, Ca, Cu and Fe content compared to DW-M, which was probably an effect of the presence of SW in the formulation.

\subsection{Evaluation of the Foliar Application of SW on the Content of Secondary Metabolites in Maize Grains}

The liposoluble fraction of antioxidant activity and the bound phenolic compounds content was higher than hidrosoluble fraction of antioxidant activity and the free phenolic compounds content in all treatments (Figures 3(a) and (b)). The liposoluble fraction of antioxidant activity corresponded to about $80 \%$ of the total antioxidant activity and showed $0.51(\mathrm{p}<0.01$ by Spearman's test) of correlation with total carotenoids (Figure 4(a)), indicating an important role of these compounds on antioxidant activity of maize grains.

The foliar application of SW increased the levels of total phenolic compounds in maize grains, compared to the other treatments (Figure 3(b)), due to the increase in bound phenolic content. This result was observed when both doses of SW was applied (SW-1 and SW-2), indicating no dose dependent effect. However, total antioxidant activity was significantly higher in grains from the SW-2 treatment, due to the higher activity of liposoluble fraction (Figure 3(a)), probably related to the increase in total carotenoids also observed in this treatment (Figure 4(a)).

The expression of PSY1, a key gene of carotenoid metabolic pathway, was $1.408,1.321$ and 2.157 fold higher than the control in the treatments SW-M, SW-1 and SW-2, respectively. CYP97C and HYD3 genes were also upregulated in the DW-M, SW-1 and SW-2 treat- ments compared to control, and they were more expressed in SW-2 treatment than the other treatments. In SW-2 treatment, there was also a HYD3/CYP97C expression ratio of 4.5 folds (Figure $4(\mathbf{b})$ ), indicating a greater allocation to the carotenoids from the $\beta, \varepsilon$-branch of carotenoid metabolic pathway $(\beta$-carotene, $\beta$-cryptoxanthin and zeaxanthin), which represent an increase of vitamin A precursors. The greater allocation to carotenoids from the $\beta, \varepsilon$-branch was also observed in the other treatments; however the HYD3/CYP97C expression ratio values were lower than in the SW-2 treatment (C - 3.7 fold; DW-M - 3.9 fold; SW-M - 3.2 fold; SW-1 3.8 fold). In summary, there was a close relationship between transcript accumulation and carotenoids content, indicating that transcription and physiological response occurs simultaneously. In addition, this metabolism was significantly stimulated by the application of three doses of $7 \mathrm{~L} /$ ha SW.

\section{DISCUSSION}

Foliar spraying of fertilizers and/or biostimulants has been considered an important strategy to biofortify crops, because it has shown to improve absorption and/or translocation of minerals via xylem, it enhances vegetative growth and yield and it may stimulate the synthesis of nutritional and functional compounds [3,9,11]. In the present study, the foliar application of three doses of 7L/ha shale water (SW-2), distributed throughout the crop cycle (see material and methods section), resulted in the increase of grain yield and the improvement in the accumulation of mineral nutrients as well as nutritional and functional compounds.

The minerals that were increased in grains following the application of SW-2 (compared to the control) include $\mathrm{K}, \mathrm{Cu}, \mathrm{Fe}, \mathrm{Mn}$ and $\mathrm{Zn}$ (Table 2). Some of these minerals, such as $\mathrm{K}, \mathrm{Cu}$ and $\mathrm{Mn}$, play an important role in photosynthesis $[4,25]$, which could contribute to explain the better performance to generate energy and to convert it into structural and storage plant compounds, 


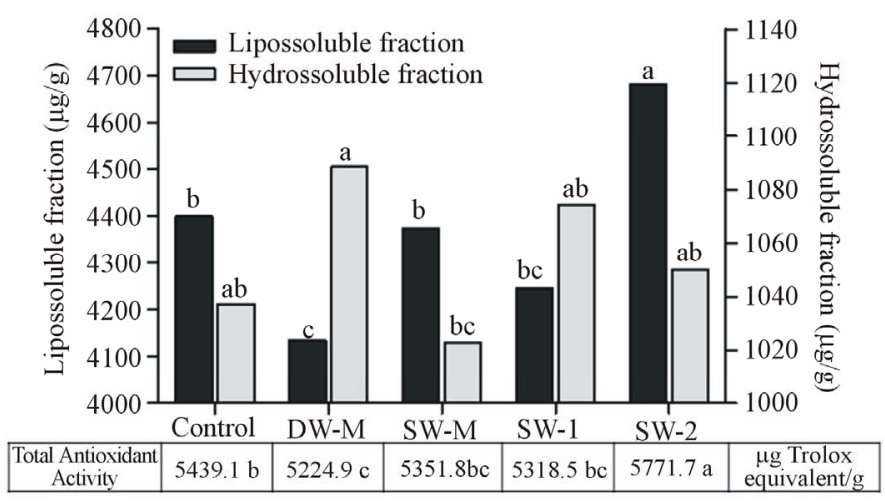

(a)

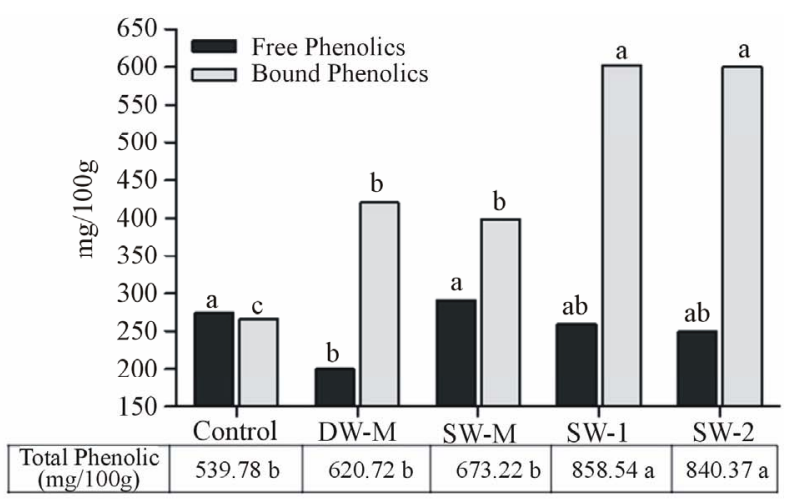

(b)

Figure 3. (a) Antioxidant activity of liposoluble and hydrosoluble fractions of maize grains harvested at R4 stage. Data are presented in microgram equivalent Trolox per gram of grain $(\mu \mathrm{g} / \mathrm{g})$. (b) Free and bound phenols of maize grains harvested at R4 stage. Data are presented in milligrams of chlorogenic acid equivalents per 100 grams of grain (mg/100). Data shows means of five field and two analytical replicates. Different letters represent significant difference at $5 \%$ confidence level by Tukey test for the same dependent variable.

(a)

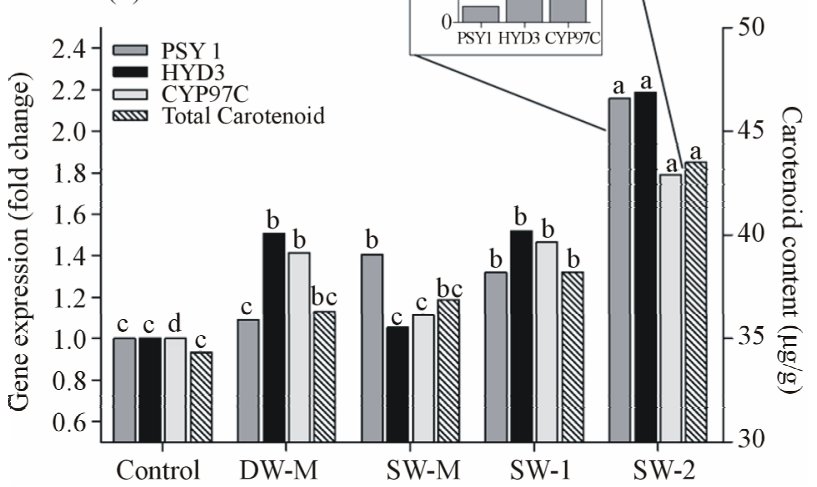

Figure 4. (a) Total carotenoids content and the relative expression of carotenogenic genes. The carotenoid content is presented as $\mu \mathrm{g}$ of $\beta$-carotene equivalents/g. The Control treatment was used as reference treatment to obtain the relative expression of the genes encoding for phytoene synthase (psy1), $\varepsilon$-carotene hydroxylase (Cyp97c) and $\beta$-carotene hydroxylase (Hyd3) in maize grains sprayed with six foliar fertilization and harvested at R4 stage. (b) Relative expression of Cyp97c and Hyd3 compared to psy1 expression in maize grains sprayed with foliar fertilization SW-2 (7 L/ha SW). Different letters represent significant differences at $5 \%$ confidence level by Tukey test.

whereas a significantly increase in yield (Figure 1(a)) with a positive correlation with starch content in grains (Figure 1(b)) was observed in plants treated with SW-2. Accumulation of $\mathrm{K}$ is also associated with the improvement of nutrients absorption, because it is responsible for the correct osmotic gradient, and plays a role in the transport of photoassimilates in plants [4]. Moreover, $\mathrm{Mn}$ has shown positive influence in grains yield [24,26], and its foliar application has also improved seed quality [27].

Despite yield remains the major aim of agronomic efforts, quality of maize grains is of great importance, particularly for people whose main source of food is this cereal. SW-2 application, besides improving yield, was able to induce the accumulation of essential mineral nutrients (Table 2), several amino acids, and starch (Figure 1(b)), which is important to provide energy in diet, acting in the reduction of cholesterol and stimulating the immune system, among others [28]. Total antioxidant activity was also significantly increased due to the application of SW-2 treatment (Figure 3(a)) by inducing high levels of bound phenolic compounds (Figure 3(b)) and total carotenoids contents (Figure 4(a)), both related to the prevention of chronic diseases [7].

Studies towards the biofortification of carotenoids in maize, especially those with provitamin A activity ( $\alpha$ and $\beta$-carotene and cryptoxanthin), have also been a focus of great interest because of the nutritional effects provided by its ingestion $[21,29]$. The application of SW-2 treatment resulted in the improvement of total carotenoids accumulation in maize grains, which was shown to be directly related to the upregulation of key genes in this metabolism (Figure 4(a)). As far as we know, this is the first survey on the evaluation of the influence of fertilization on induction of these genes, despite the fact that they are widely known and studied in maize [21]. The induction of transcript levels (approximately two fold higher than control) occurred at the beginning of this metabolic pathway, increasing PSY1 expression (coding for the enzyme phytoene synthase) and at the end, increasing the expression of genes encoding for enzymes directly associated to the synthesis of $\beta$-carotene, $\beta$ cryptoxanthin and zeaxanthin (HYD3), and lutein synthesis (CYP97C) [21]. In all treatments there was a greater allocation to the production of compounds from 
metabolic pathway branch associated to HYD3 expression instead of the ones associated to CYP97C expression (Figure 4(b)), probably because yellow grains, such as those from the hybrid variety used in this study usually shows high zeaxanthin/lutein content ratio [29,30]. Therefore, there was a greater allocation to the production of provitamin A carotenoids in all treatments, representing an efficient biofortification approach.

It is interesting to note that usually a negative correlation is observed between primary metabolites and total phenolic compounds [31,32]. In this study, SW-M treatment showed increased $\mathrm{N}$ accumulation (Table 2) and yield (Figure 1(a)), and did not increase the levels of phenolic compounds (Figure 3). This effect would occur by competition with phenylalanine, a precursor for both phenolic compounds and protein [31]. Similarly, in the SW-2 treatment, the yield and starch content increased while the free phenolic compounds content and hydrosoluble fraction of antioxidant activity decreased. However, in the SW-2 treatment, the lipophylic fraction of antioxidant activity and the content of bound phenolic compounds, which corresponds to the major fraction of phenolic compounds in maize grains, also increased (Figure 3). Therefore, the application of SW-2 treatment was able to induce primary and secondary metabolisms in maize, possibly because a third application of the treatments was performed during the reproductive phase of maize plants, providing an extra amount of nutrients. These nutrients were then used in the production of secondary metabolites. Similar effects were obtained with foliar fertilization combined with a growth regulator activity compound [33] and with the application of several elicitors/biostimulants [11]. The increase of secondary metabolites in maize grains following the application of SW may also be a result of a moderate non-harmful stress in plants as was evidenced by the increase of valine, asparagine, alanine and proline (Figure 2) in maize grains following the application of SW-2. These last two amino acids are related to stress tolerance. Alanine play a role in the intracellular $\mathrm{pH}$ regulation in hypoxia stress condition [34]. The accumulation of free proline in plants is widely observed in different abiotic stresses such as salinity and drought, acting in the stomata opening regulation and osmotic processes. Studies show the influence of this amino acids in the synthesis of phenolic compounds [35], corroborating the data observed in SW-2 treatment.

The enrichment of SW with micronutrients according to maize crop requirement was also investigated (SW-M treatment) in order to verify if the effect of SW could be improved by this approach. Indeed, supplementation with micronutrients, including mainly $\mathrm{Zn}$, allowed increased $\mathrm{Zn}$ accumulation (Table 2), representing a great nutritional and functional improvement, since this min- eral is essential as transcript cofactor and plays a role in the antioxidant defense [4]. However, is important to evaluate its bioavailability in humans due to the presence of phytate in maize grains. In plants, $\mathrm{Zn}$ has shown a direct relationship with yield [9], also observed in the treatment SW-M (Figure 1(a)). Besides Zn accumulation and yield, the content of some free amino acids was also improved in treatment SW-M (Figure 2). However, for most of the other parameters, SW delivered alone in three doses of $7 \mathrm{~L} / \mathrm{ha}(\mathrm{SW}-2)$ presented better results than SW-M.

\section{CONCLUSION}

The results of this study showed that the use of foliar application of SW-2 influenced mineral and primary metabolites accumulation, which resulted in significant increase in yield. This treatment also resulted in the improvement of secondary metabolites, such as bound phenolics and carotenoids, probably due to the later application during the reproductive stage. The enrichment of SW with minerals potentiated the effect of SW delivered alone regarding the improvement of free amino acids and some minerals, especially $\mathrm{Zn}$; however, the accumulation of several minerals, amino acids, starch, carotenoids and phenolic compounds were higher when SW was delivered without nutrient supplementation. In this context, the application of three doses of $7 \mathrm{~L} / \mathrm{ha} \mathrm{SW}$ results in great improvement in grain yield and quality. However, further studies are necessary to optimize SW doses and better understand SW mechanisms of action.

\section{REFERENCES}

[1] Wang, L., Xua, C., Qua, M. and Zhang, J. (2008) Kernel amino acid composition and protein content of introgression lines from Zea mays ssp. mexicana into cultivated maize. Journal of Cereal Science, 48, 387-393. http://dx.doi.org/10.1016/j.jcs.2007.09.014

[2] Kuhnen, S., Lemos, P.M., Campestrini, L.H., Ogliari, J.B., Dias, P.F. and Maraschin, M. (2011) Carotenoid and anthocyanin contents of grains of Brazilian maize landraces. Journal of the Science of Food and Agriculture, 91, 1548-1553. http://dx.doi.org/10.1002/jsfa.4346

[3] Gomez-Galera, S., Rojas, E., Sudhakar, D., Zhu, C., Pelacho, A.M., Capell, T. and Christou, P. (2010) Critical evaluation of strategies for mineral fortification of staple food crops. Transgenic Research, 19, 165-180. http://dx.doi.org/10.1007/s11248-009-9311-y

[4] Messias, R.S, Galli, V., Silva, S.D.A., Schirmer, M.A. and Rombaldi, C.V. (2013) Micronutrient and functional compounds biofortification of maize grains. Critical Reviews in Food Science and Nutrition, in Press. http://dx.doi.org/10.1080/10408398.2011.649314

[5] Sosulski, F., Krygier, K. and Hogge, L. (1982) Free, esterified, and insoluble bound phenolic acids. Composition 
of phenolic acids in cereal and potato flours. Journal of Agricultural and Food Chemistry, 30, 337-340. http://dx.doi.org/10.1021/jf00110a030

[6] De Oliveira, G.P.R. and Rodriguez-Amaya, D.B. (2007) Processed and prepared corn products as sources of lutein and zeaxanthin: Compositional variation in the food chain. Journal of Food Science, 72, S079-S085. http://dx.doi.org/10.1111/j.1750-3841.2006.00235.x

[7] Fraser, P.D. and Bramley, P.M. (2004) The biosynthesis and nutritional uses of carotenoids. Progress in Lipid Research, 43, 228-265.

http://dx.doi.org/10.1016/j.plipres.2003.10.002

[8] WHO (2009) Global prevalence of vitamin A deficiency in populations at risk 1995-2005, in WHO Global Database on Vitamin A Deficiency. World Health Organization, Geneva, 1-55.

[9] Cakmak, I. (2008) Enrichment of cereal grains with zinc: Agronomic or genetic biofortification? Plant Soil, 302, 1-17. http://dx.doi.org/10.1007/s11104-007-9466-3

[10] Brakemeier, C. (1999) Adubação foliar: A complementação nutricional da macieira. Jornal da Fruta, Lajes, 7.

[11] Ruiz-García, Y. and Gómez-Plaza, E. (2013) Elicitors: A tool for improving fruit phenolic content. Agriculture, 3, 33-52. http://dx.doi.org/10.3390/agriculture3010033

[12] Messias, R.S., Silveira, C.A.P., Galli, V., Pillon, C.N. and Rombaldi, C.V. (2013) Multimineral and organic composition of a liquid by-product from the pyrobituminous shale pyrolysis process and its potential use in agriculture. Journal of Plant Nutrition, in Press.

[13] Pereira, S.H.E. and Mello, C.S. (2002). Foliar fertilizer applications on nutrition and yield of sweet pepper and tomato. Horticultura Brasileira, 20, 597-600. http://dx.doi.org/10.1590/S0102-05362002000400017

[14] Hanway, A.L. (1966) How a corn plant develops. Iowa Agricultural Experiment Station, Iowa, 15p. (Special Report, 48).

[15] Magalhães, P.C. and Durães, F.O.M. (2006) Fisiologia da produção de milho. Embrapa Milho e Sorgo, Embrapa Milho e Sorgo, Sete Lagoas, Circular Técnica, 76.

[16] Hodge, J.E. and Hofreiter, B.T. (1962) Determination of reducing sugars and carbohydrates. In: Whistler, R.L. and Wolfrom, M.L., Eds., Methods in Carbohydrate Chemistry, Academic Press, New York, 380-394.

[17] Da Silva, F.C. (2009) Manual de análises químicas de solos, plantas e fertilizantes. 2nd Edition, Embrapa Informação Tecnológica, Brasília.

[18] Arnao, M.B., Canoa, A. and Acosta, M. (2001) The hydrophilic and lipophilic contribution to total antioxidant activity. Food Chemistry, 73, 239-244. http://dx.doi.org/10.1016/S0308-8146(00)00324-1

[19] Adom, K.K. and Liu, R.H. (2002) Antioxidant activity of grains. Journal of Agricultural and Food Chemistry, 50, 6182-6187. http://dx.doi.org/10.1021/jf0205099

[20] Rodriguez-Amaya, D.B. and Kimura, M. (2004) HarvestPlus handbook for carotenoid analysis. HarvestPlus Technical Monograph, Washington DC and International Food Policy Research Institute (IFPRI) and International
Center for Tropical Agriculture (CIAT), Cali.

[21] Vallabhaneni, R. and Wurtzel, E.T. (2009) Timing and biosynthetic potential for carotenoid accumulation in genetically diverse germplasm of maize. Plant Physiology, 150, 562-572. http://dx.doi.org/10.1104/pp.109.137042

[22] Messias, R.S, Galli, V., Silva, S.D.A., Schirmer, M.A. and Pillon, C.N. (2010) Extraction RNA methodologies and semi quantitative gene expression evaluation of maize secondary metabolism (Zea mays L.). Boletim de Pesquisa e Desenvolvimento: Embrapa Clima Temperado, 117, 1-25.

[23] Livak, K.J. and Schmittgen, T.D. (2001) Analysis of relative gene expression data using real-time quantitative PCR and the $2^{-\triangle \Delta C T}$ method. Methods, 25, 402-408. http://dx.doi.org/10.1006/meth.2001.1262

[24] Abbas, G., Khan, M.Q., Khan, M.J., Tahir, M., Ishaque, M. and Hussain, F. (2011) Nutrient uptake, growth and yield of wheat (Triticum aestivum L.) as affected by manganese application. Pakistan Journal of Botany, 43, 607-616.

[25] Kirchmann, H. and Eskilsson, J. (2010) Low manganese $(\mathrm{Mn})$ and copper $(\mathrm{Cu})$ concentrations in cereals explained yield losses after lime application to soil. Acta Agriculturae Scandinavica, 60, 569-572.

[26] Gordon, B. (2007) Manganese nutrition of glyphosateresistant and conventional soybeans. Better Crops, 91, 12-13.

[27] Dordas, C. (2009) Foliar application of manganese increases seed yield and improves seed quality of cotton grown on calcareous soils. Journal of Plant Nutrition, 32, 160-176. http://dx.doi.org/10.1080/01904160802609013

[28] Meyer, K.A., Kushi, L.H., Jacob, D.R.J., Slavin, J., Sellers, T.A. and Folsom, A.R. (2000) Carbohydrates, dietary fiber, incident type 2 diabetes mellitus in older women. The American Journal of Clinical Nutrition, 71, 921-930.

[29] Zhu, C., Naqvi, S., Breitenbach, J., Sandmann, G., Cristou, P. and Capell, T. (2008) Combinatorial genetic transformation generates a library of metabolic phenotypes for the carotenoid pathways in maize. Proceeding of the $\mathrm{Na}$ tional Academy of Science, 105, 18232-18237.

[30] Fanning, K.J., Martin, I., Wong, L., Keating, V., Puna, S. and O'Harec, T. (2010) Screening sweetcorn for enhanced zeaxanthin concentration. Journal of the Science of Food and Agriculture, 90, 91-96. http://dx.doi.org/10.1002/jsfa.3787

[31] Herms, D.A. and Mattson, W.J. (1992) The dilemma of plants: To grow or defend. Quarterly Review of Biology, 67, 283-335. http://dx.doi.org/10.1086/417659

[32] Glynn, C., Herms, D.A., Orians, C.M., Hansen, R.C. and Larsson, S. (2007) Testing the growth-differentiation balance hypothesis: Dynamic responses of willows to nutrient availability. New Phytologist, 176, 623-634. http://dx.doi.org/10.1111/j.1469-8137.2007.02203.x

[33] Geneva, M., Stancheva, I., Sichanova, M., Boychinova, M., Georgiev, G. and Dolezal, M. (2008) Improvement of milk thistle (Silybum marianum L.) seed yield and quality with foliar fertilization and growth effector MD 148/II. General and Applied Plant Physiology, 34, 309-318. 
[34] Miyashita, Y., Dolferus, R., Ismond, K.P. and Good, A.G. (2007) Alanine aminotransferase catalyses the breakdown of alanine after hypoxia in Arabidopsis thaliana. The Plant Journal, 49, 1108-1121.

http://dx.doi.org/10.1111/j.1365-313X.2006.03023.x
[35] Ashraf, M. and Foolad, M.R. (2007) Roles of glycine betaine and proline in improving plant abiotic stress resistance. Environmental and Experimental Botany, 59, 206-216.

http://dx.doi.org/10.1016/j.envexpbot.2005.12.006 